\title{
A Double Whammy for the History of Evangelical Protestantism
}

\author{
David A. Hollinger
}

Most histories fail to convincingly explain why 81 percent of American white evangelical voters supported Trump in the 2016 election. Many scholars, like political pundits, hold an idealized vision of the evangelical past, which leads them to assume that "real" evangelicals are actually not so enthusiastic about the deeply anti-intellectual, frankly authoritarian, materialistic, and sexually promiscuous media personality who won the White House. ${ }^{1}$ The history of evangelical thought and action after all includes many examples of sensible, humane, and intellectually creative work. How could such a wholesome religious tradition as evangelical Protestantism possibly share responsibility for the political success of Donald Trump?

This argument reaches its extreme in a recent essay by George M. Marsden, one of the most accomplished and influential historians of evangelicalism. "If there were a Democratic Trump," Marsden opines, "lots of Democrats who were Christian would loyally fall into line, often with great enthusiasm." The problem, he explains, is not with the culture of evangelicalism at all. Ecumenical Protestants favoring the Democrats have not behaved like evangelicals because they have not been pushed. The problem is "the ironic flaw in human nature that Reinhold Niebuhr identified, that a too confident sense of justice often leads to injustice." All this evangelical support for Trump is an example of the regrettable "allying with the powers of darkness in order to gain political power." This "selective blindness in human nature operates not just on our political opponents but on all of us." " So, enough already. We are all sinners. Let's change the subject. Stop talking about how bad evangelicals are.

Yet some scholars insist that the disreputable rag-tag of ignorant pro-Trumpites are not, as Fred Clark argues, "a slice of the evangelical world," but "are that world. They are the majority of it." ${ }^{3}$ Two recent books offer especially illuminating hints of a more critical perspective on evangelicalism's past and present: Darren Dochuk's Anointed with Oil: How Christianity and Crude Made Modern America and Kristin Kobes Du Mez's Jesus and John Wayne: How White Evangelicals Corrupted a Faith and Fractured a Nation. Taken together, they constitute a veritable double whammy in the reorientation of the study of evangelical Protestantism as a force in the history of modern America.

Dochuk shows that oil magnates espousing evangelical styles of religion influenced American public life in directions very different from the influence exercised by their counterparts in the ecumenical, or "mainline," denominations, and that this has been true since the

\footnotetext{
${ }^{1}$ See, for example, Michael Gerson, "Evangelicals Must Not Bare the Mark of Trump," Washington Post, June 2, 2016, https://www.washingtonpost.com/opinions/evangelicals-may-carry-the-mark-of-trump/2016/06/02/dc0f59b4-28eb11e6-ae4a-3cdd5fe74204_story.html (accessed March 30, 2020).

${ }^{2}$ George M. Marsden, “On Not Mistaking One Part for the Whole: The Future of American Evangelicalism in a Global Perspective," in Evangelicals: Who They Have Been, Are Now, and Could Be, eds. Mark A. Noll, David W. Bebbington, and George M. Marsden (Grand Rapids, MI, 2019), 281-91, here 290-1.

${ }^{3}$ Fred Clark, "The 'Weird' Fringe Is the Biggest Part of White Evangelicalism," in Evangelicals: Who They Have Been, Are Now, and Could Be, eds. Mark A. Noll, David W. Bebbington, and George M. Marsden (Grand Rapids, MI, 2019), 241-4, here 243.

(C) The Author(s) 2020. Published by Cambridge University Press. This is an Open Access article, distributed under the terms of the Creative Commons Attribution licence (http://creativecommons.org/licenses/by/4.0/), which permits unrestricted re-use, distribution, and reproduction in any medium, provided the original work is properly cited.
} 
late-nineteenth century. Historians have long understood that in the middle and late decades of the twentieth century, conservative oil men like J. Howard Pew financed evangelical institutions and facilitated the political ascendancy of anti-statist Republicans like Ronald Reagan. ${ }^{4}$ But Dochuk casts this tradition into bold relief by documenting with equal rigor what he calls "the Civil Religion of Crude." Central to that tradition was the Rockefeller family, starting with the original John D.'s Northern Baptist-based financing of the University of Chicago, running through John D. Jr's extensive support of the ecumenical and social welfare initiatives of the Federal Council of Churches, then continuing through the Rockefeller Foundation's philanthropies and Nelson Rockefeller's leadership of the liberal wing of the Republican Party, and culminating in the next generation's embrace of environmentalism. Missionary intensive and global in scope, the Civil Religion of Crude produced Aramco, the company that developed the oil industry of Saudi Arabia and made a huge production of trying to establish a Christian-Muslim alliance in world affairs.

How different was "Wildcat Christianity," Dochuk's label for the countless independent drillers like Pew and H. L. Hunt who linked the individual-salvation doctrines of the Fundamentalists with a determination that government should do nothing to limit their own ability to drill for oil and reap the resulting profits? These Christ-only, Islamophobic, Americo-centric, heavily Texas-based entrepreneurs embraced "the mysteries of an earth whose hidden riches enchanted and eluded reason" and held tightly to "a theology premised on the power of personal encounter with an active Creator." While the oilers of the mainline, ecumenical persuasion were interested in "rebuilding society with complex man-made rationales," the wildcatting evangelicals favored "saving souls with their simple gospel." The premillennialist Sarah Palin, with her slogan, "drill baby, drill," fits into this tradition. By demonstrating how stark was the contrast between these two styles of oil-related Protestantism, Dochuk has given us one of the finest case studies ever written of the ecumenical-evangelical divide and of the significance of that divide in the public life of the United States. ${ }^{6}$ Although explaining the evangelicals-for-Trump phenomenon is not among Dochuk's explicit goals, he puts before us aspects of evangelical history that render that phenomenon unsurprising. Trump talks and acts like a wildcatter.

$\mathrm{Du} \mathrm{Mez}$ also establishes that an accurate history would predict evangelical enthusiasm for Trump. While the most intellectually ambitious and skilled of evangelical leaders of the twentieth century wrestled with hermeneutic complexities - what did the Bible really mean and how do we know? - a parallel "evangelical culture of consumption" flourished, which, Du Mez argues, consistently celebrated the hyper-masculine, swaggering movie star John Wayne as the ideal Christian. ${ }^{7}$ Many educated, well-positioned church leaders were untroubled by the religious sensibilities that dominated this popular culture, but those who were troubled proved unable to control it. Church-goers (not just the rarely church attending, but evangelically identified citizens) proved more loyal to this popular culture than to any list of doctrines endorsed

\footnotetext{
${ }^{4}$ Awareness of this aspect of modern American history has been most effectively advanced by Kevin Kruse, One Nation Under God: How Corporate America Invented Christian America (New York, 2015), but Dochuk offers a longer time line, distinguishes more sharply between the evangelical and ecumenical variations on the theme, and demonstrates the unique importance of the oil industry.

${ }^{5}$ Darren Dochuk, Anointed by Oil: How Christianity and Crude Made Modern America (New York, 2019$), 13$.

${ }^{6}$ The understanding of American Protestant history as a series of episodes in a "two-party system" was developed by Martin Marty, in what remains after a half-century the best single book addressing that history, Righteous Empire: The Protestant Experience in America (New York, 1970). Two recent books written in Marty's tradition are David A. Hollinger, After Cloven Tongues of Fire: Protestant Liberalism in Modern American History (Princeton, NJ, 2013), and David A. Hollinger, Protestants Abroad: How Missionaries Tried to Change the World but Changed America (Princeton, NJ, 2017).

${ }^{7}$ Kristin Kobes Du Mez, Jesus and John Wayne: How White Evangelicals Corrupted a Faith and Fractured a Nation (New York, 2020), 8. See also Molly Worthen, Apostles of Reason: The Crisis of Authority in American Evangelicalism (New York, 2014).
} 
by the seminary professors who wrote for Christianity Today or the historians who edited Evangelicals. Du Metz is forthright:

Evangelical support for Trump was no aberration, nor was it merely a pragmatic choice. It was, rather, the culmination of evangelicals' embrace of militant masculinity, an ideology that enshrines patriarchal authority and condones the callous display of power, at home and abroad. By the time Trump arrived proclaiming himself their savior, conservative white evangelicals had already traded a faith that privileges humility and elevates "the least of these" for one that derides gentleness as the province of wusses.... In reality, evangelicals did not cast their vote despite their beliefs, but because of them. ${ }^{8}$

The "militant masculinity" central to Du Mez's story was advanced by countless independent religious entrepreneurs whose ambience is rather like Dochuk's Wildcat Christians. The blatantly misogynistic Seattle preacher, Mark Discroll, is one whose career Du Mez follows closely. The most important was the psychologist who did more than any other individual to develop "family values" as a homophobic, antifeminist program for politics and culture, James Dobson. Presidents of Christian colleges shared as their "greatest fear" that "Dobson would turn against their school." Pastors found that their own influence over their parishioners paled by comparison with the authority Dobson exercised over them. John Wayne may have embodied the most popular Hollywood heroes, but the characters played by Mel Gibson were not far behind. Gibson's Scottish warrior William Wallace in Braveheart was repeatedly cited as a role model for men. Lt. Col. Oliver North, indicted on sixteen felony counts for his orchestration of illegal support for the Nicaraguan Contras, became a cult figure for his defiance of timid, law-abiding officials. North was no wimp, unlike Jimmy Carter, who was "born again" and a conscientious churchman but who wore cardigans and prioritized human rights.

Although Billy Graham was never as outrageous as North, Du Mez reminds us that the greatest American evangelical of them all was a calculated creation in the tradition of charismatic male revivalists, going back to Billy Sunday and beyond. Graham had once thought of religion as something for girls, old women, and "sissies," but he grew to appreciate Jesus as "every inch a man." Graham consistently allied himself with hawkish politicians, condemning as "cowardly" Harry Truman's rejection of General MacArthur's call for a wider and more aggressive war beyond Korea. Commenting in 1971 on the My Lai Massacre, Graham fell into line with the right-wing politicians, allowing that he "never heard of a war where innocent people are not killed," and that "we have all had our Mylais in one way or another, perhaps not with guns, but we have hurt others with a thoughtless word, an arrogant act or a selfish deed." 10 During the years of his greatest influence, Graham was a vigorous defender of patriarchy, declaring the male to be "God's representative" and telling wives to provide husbands with "love at any cost." 11

$\mathrm{Du}$ Mez's most persistent theme is the systematic, overt, strictly enforced opposition to the expansion of women's role beyond traditional matrimony, sex on demand, and motherhood. If the point did not so desperately need to be made, and loudly, one might tire of Du Mez's endless parade of examples. Here is one-her account of the gender theory defining Stu Weber's popular book of 1993, Tender Warrior:

\footnotetext{
${ }^{8} \mathrm{Du} \mathrm{Mez}$, Jesus and John Wayne, 3.

${ }^{9}$ Ibid., 207.

${ }^{10}$ Ibid., 49-50.

${ }^{11}$ Ibid., 23, 26, 49.
} 
Man, at his core, was tough and strong, a risk taker, "an initiator-a piercer, one who penetrates, moves forward, advances toward the horizon, leads." Women, on the other hand, preferred security and order; they were the gentle responders, tender companions, "aloneness fighters." These differences were woven through all of Scripture, and nothing was more pitiful "than a man forfeiting his masculinity or a woman her femininity by transgressing the created order."12

The popular culture of evangelicalism was often crude, but perhaps the most important single take-away from Jesus and John Wayne is how little resistance to it respectable evangelical leaders offered, and how often they enabled it. In a devastating chapter entitled "Evangelical Mulligans: A History," Du Mez reviews a sequence of scandals, most of which involved sexual abuse by male clergy. Some leaders of major evangelical organizations, denominations, and seminaries reacted with horror, but others gave the perpetrator "a mulligan," as Tony Perkins of the Family Research Council famously phrased his 2016 forgiving of Trump's sexual misconduct. Evangelicals were the real victims, Perkins explained. After being "kicked around by Barack Obama and his leftists," it is good that someone-Trump-was ready to "punch the bully." 13

Both Jesus and John Wayne and Anointed with Oil illustrate how the selective use of scripture by people who believe in its absolute, literal, and timeless truth can embolden them to isolate themselves from sources of information and insight more accessible to people who understand the historicity of the Bible and of themselves. The Bible contains 31,201 verses, every one of which is deeply embedded in a distinctive historical context. ${ }^{14}$ There are other sources of blindness, of course, but most of Du Mez's cast of characters and many of Dochuk's were oblivious to how their claims of scriptural warrant reflected choices they had made, driven by their own worldly interests.

David A. Hollinger is Preston Hotchkis Professor of History Emeritus at the University of California, Berkeley, CA, USA. He is an elected member of the American Philosophical Society and the American Academy of Arts and Sciences, and is a former president of the Organization of American Historians. His recent publications include "The Global South, Christianity, and Secularization: Insider and Outsider Perspectives" (Modern Intellectual History, 2020) and When This Mask of Flesh Is Broken (Outskirts Press, 2019).

\footnotetext{
${ }^{12}$ Ibid., 164.

${ }^{13}$ Ibid., 276.

${ }^{14}$ John Barton, A History of the Bible: The Story of the World's Most Influential Book (New York, 2019).
} 